\title{
ECONOMIC BASE SCENARIO ASSESSMENT OF INNOVATIVE PRODUCT MANUFACTURING FROM BALTIC SEA SPRATS (SPRATTUS SPRATTUS BALTICUS)
}

\author{
Janis Ozolins ${ }^{1}$, Irina Pilvere ${ }^{2 *}$, Aleksejs Nipers ${ }^{2}$, Mihails Silovs $^{2}$, Liga Proskina ${ }^{2}$, Olga Dmitrijeva ${ }^{2}$ \\ ${ }^{1}$ Corporate Management Experts Bureau Ltd, Baznicas street 13-17, Riga, Latvia \\ ${ }^{2 *}$ Faculty of Economics and Social Development, Latvia University of Life Sciences and Technologies, Svetes street 18, \\ Jelgava, Latvia, e-mail: irina.pilvere@llu.lv
}

\begin{abstract}
Fisheries have a long history and tradition in Latvia. In recent years, the fish processing subsector has been challenged by the development and introduction of new and innovative products manufactured from Baltic Sea sprats (Sprattus sprattus balticus), which serve as an alternative to canned sprat production. Therefore, the aim of the present research was to perform an economic assessment of the establishment of a potential factory for the production of innovative fish products from sprats caught in the Baltic Sea. To achieve the aim, two specific research tasks were set: 1) to perform a financial and efficiency analysis of the investment project for the industrial production of the newly developed innovative products; 2) to determine the economic effect from the establishment of the factory. The research base scenario established the minimum amount of necessary investment to start up a factory and estimated processing capacity at 408 tons of sprats a year to pay back the investment in time by producing two new innovative products from Baltic Sea sprats: fish buns and fish meatballs in jelly. The research established main economic and financial performance indicators for the investment in the factory project, calculated the number of employees needed for the factory and identified the economic benefits the factory would provide. The research found that setting up a factory within one year could reach the planned fish processing capacity in the third year of operation, reaching 4.7 million euro in turnover and 2 million euro in net profit with a $44 \%$ net margin in year 3 and onwards.
\end{abstract}

Keywords: sprats, innovative products, economic assessment

\section{Introduction}

Growing demand for fish has promoted a major expansion of European fleets in size and fishing range. According to European Commission data, more than 140000 people are employed as fishers in the European Union (EU) (Schroeer, Sakai et al., 2011). The EU catches on average approximately $6.4 \mathrm{mln}$. $\mathrm{t}$ of fish a year, while the fisheries sector (which is divided into three subsectors: fishing, aquaculture and fish processing) employs about 350 thousand people. However, the pronounced local resource depletion underlines the need for close cooperation between industry and the public sector to counter uncertainties that act as a constraint on investment in utilization schemes (Catchpole, Ribeiro-Santos et al., 2017). Despite the mixed performance (Da Rocha et al, 2012; Khalilian et al, 2010; Sissenwine, James, 2007), the EU Common Fisheries Policy, which sets targets for as well as series of restrictions on the EU fisheries sector, is an important instrument for the sector growth.

In Latvia, the fisheries sector has a long history and tradition. This is both an advantage, as the country has developed an extensive infrastructure for fisheries and built up considerable experience, and a challenge. Since 2014 when the Russian Federation imposed restrictions on imports of fish products from Latvia, the market has made the fisheries sector go beyond the comfort area for the large-scale production of conventional fish products. As pointed out by Laugalis (2009), a number of significant problems, which need political solutions at the national and European levels, exist in the fisheries sector of Latvia. The most significant is the available resources of fish for catching and processing. Since 2005, the key initiative in regulating fishing and in setting fishing quotas in the
Baltic Sea belongs to the European Commission, as the volume of catches by the European Union Member States in the Baltic Sea accounts for $95 \%$ of the total. The Baltic Sea sprat is the most significant fish species in terms of percentage of the total fishing quota for Latvia. In 2017, Latvian fishermen caught 35.7 thou.t of sprats, which was 7.6 thou.t more than in 2016. The total allowable catch for 2017 was increased by $29 \%$. In 2017, Latvia's fishing quota for sprats equalled $36107 \mathrm{t}$, which was exhausted by $99 \%$. In 2017, the total catch of sprats by all the EU Member States equalled 285.7 thou.t or 39.2 thou.t more than in 2016. Overall, the EU Member States exhausted their quotas for sprats by $94.6 \%$ (Kornilovs, Ustups, 2018).

In the period 2012-2016, according to the Central Statistical Bureau (2019), the fish processing subsector of Latvia sharply decreased the processing of sprats $(-41 \%)$, and this input was imported significantly less $(-50 \%)$, while the volume of catches remained at the same level. Because of the restrictions on fish product imports imposed by the Russian Federation, the market for products made from sprats considerably shrank, and fish processors were forced to significantly decrease their output. Consequently, a considerable quantity of this raw material was not required, and the exports of sprats from Latvia rose by $51 \%$, reaching as many as 27.7 thou. $\mathrm{t}$ in 2017.

Ankvica (2018) points out that an analysis of the results of 2017 reveals that Latvian fish processors, working under the sanctions of the Russian Federation, actively sought new sales partners in various countries. Nevertheless, there are several reasons of the slow expansion of the market. One of the key reasons is the fact that in Latvia, canned sprat and Baltic herring still dominate in the production of prepared and canned fish. 
Benga and Hazners (2018), however, point out that in Latvia, the fish product segment has been always mainly export-oriented. The capacity of the domestic market is limited, and the domestic consumption has been slightly declining for many years. Approximately $85 \%$ of fish production is exported. Fishing quotas for a number of significant fish species have been reduced or will be reduced in the future too; consequently, fishermen and fish processors have to consider this trend already now. New ways have to be sought to process the very limited fish resources and generate maximum value-added so that funds are accumulated for the further development of this sector.

As indicated by Neiva et al. (2010) fish mince production is equally beneficial in terms of economic profit for producers since it allows utilisation of low value species (i.e. due to its small shape) and it also diminishes the volume of processing by-products promoting rational use of the limited catch. According to the estimations provided by the Food and Agriculture Organization of the United Nations (2001) the introduction of fish mince processing can increase the yield from $8 \%$ to up to $50 \%$ in comparison to traditional filleting alone. However, despite the fact that for certain fish species minced fish production is a well-established process (Neiva et al., 2010), the present market for the minced fish products meant for human consumption is not saturated despite the growing demand. The expansion of the market is significantly hindered by technological and production challenges that should be addressed virtually for each fish species individually mainly obtaining preferable colour of the final product, its structure as well as organoleptic features acceptable for the final user. In addition, fish mince manufacturing requires increased hygienic and processing care due to mince's rapid spoilage in comparison to traditional products. Currently, the minced fish (various species) is used for manufacture of fish four, fish cakes, (cheaper) fish fingers, surimi, kemaboko, and as a filler in laminated filler blocks with up to $15 \%$ mince. There also were attempts to produce fish crackers from minced fish and starch, fish patties from minced rockfish meat (Destura, Haard, 1999) and from minced Indian major carp (Seghal et al., 2008).

In Latvia, as pointed out by the Ministry of Agriculture (Ministry of Agriculture, 2018), very diverse fish products are produced: frozen, salted and smoked fish, unsterilized preserves and ready-to-serve products as well as sterilized canned fish. The fish-processing subsector mainly processes the fish caught in the Baltic Sea. Of the entire assortment of processed fish, $66 \%$ is canned fish, the sale of which is hindered in eastern markets because of trade restrictions and lower purchasing power there. The most important raw material for the canning industry produced in Latvia are Baltic sprats. They make up about $70 \%$ of the amount of sterilized canned food. Besides the restricted market opportunities, the processing of canned sprats is known for a large amount of waste, and the resulted processed products, in fact, provide little significant added value when comparing raw fish and fish fillets. To increase the level of processing, reduce the amount of by-products and losses of valuable food raw materials, a significant number of, for example, cod processors are producing block minced cod from mechanically dumped bones using separators and neopresses. This process allows valuable fish raw materials involvement in food production, which otherwise requires either expensive disposal or, at best, results in fish flour production. The existing technology suggests that the fish mince production could be an option for the Baltic sprats processing. This introduces an important priority to create new, innovative processed products out of Baltic sprats that are demanded in currently open and prospective foreign markets in order to diversify and increase fish product exports.

Within the European Maritime and Fisheries Fund (EMFF) project No. 16-00-F01101-000005 "Production of structured fish forcemeat from Baltic sea fish and its use in fish products" an innovative structured fish forcemeat was produced out of Baltic sprats along with new, customer-ready products, the introduction of which in production requires an economic analysis.

The project developed recipes and technological knowhow for the production of seven new, innovative products from structured fish forcemeat made from Baltic sprats: fish spaghetti, fish dumplings, fish sausage, fish fingers (breaded), fish buns, fish terrine (filled with egg) and fish meatballs (in jelly). The base scenario of the research analyses the establishment of a factory for the production of two products (fish buns and fish meatballs in jelly), as the production of all the seven products requires a considerably larger initial investment, yet the available resources are limited. Therefore, the research aim was to perform an economic assessment of the establishment of a potential factory for the production of innovative fish products from sprats caught in the Baltic Sea. To achieve the aim, two specific research tasks were set:

1) to perform a financial and efficiency analysis of the investment project for the industrial production of the newly developed innovative products;

2) to determine the economic effect from the establishment of the factory.

\section{Materials and Methods}

The present research used the performance results, acquired by means of a financial model, for an investment project - the establishment of a fish processing factory producing two products from unprocessed Baltic sprats (fish buns and fish meatballs in jelly). The production process in the factory will comprise a full cycle from raw Baltic sprats to marketready products of structured fish forcemeat.

The base scenario estimated processing capacity at 408 tons of sprats per year, selling the products in the market of the Baltic States. The research developed a set of detailed assumptions based on the information provided by researchers from Faculty of Food Technology of Latvia University of Life Sciences and 
Technologies - S. Muizniece-Brasava, A. KirseOzolina, I. Gramatina, I. Ciprovica, S. Sazonova, E. Straumite, Z. Kruma, M. Sabovics, D. Kunkulberga, J. Kivite, T. Kince, J. Zagorska. Sales prices were assumed, taking into account the price level of similar products and wholesaler and retailer mark-ups. The research has assumed that the entire quantity of products is sold at EXW (ex-works) prices, as the wholesaler is responsible for marketing and distribution, and the wholesaler mark-up accounts for $15 \%$ of the retailer purchase price. In the most optimistic case, the sales prices are planned to be lower than the prices in the Baltic market, depending on product group, in order to have an opportunity to sell larger quantities in low purchasing-power markets. However, the price formation could be complicated because the products are innovative and no analogues are available in the market. For this reason, the research used the price level of the most similar products as a benchmark. The financial model assumed that the investment project for the fish processing factory would be implemented without public financial assistance. It is also assumed that the factory operates in a one-shift mode and the factory establishment project begins in January 2019, lasting for 18 months.

The financial model simulated a situation for a period of 10 years. The model simulated the cash flow by year and by month, performed profit or loss account, balance sheet, net present value and payback period calculations and cost and profit margin calculations for each product type and produced a project implementation schedule and a summary of key financial performance indicators for investors. The model also has a set of entry fields for detailed project assumptions.

The key financial performance indicators presented in the research were acquired by employing some of the calculation methods provided by DuPont analysis. DuPont analysis is a common form of financial statement analysis, which indicates that the DuPont components represent an incremental and viable form of information about the operating characteristics of a firm (Houmes, et al., 2018; Bauman, 2014; Soliman, 2008). The mentioned indicators are as follows:

1) EBIDTA - earnings before interest, taxes, depreciation and amortization, in EUR and as a \% of net turnover;

2) net margin, \%: net profit divided by net turnover and multiplied by 100 ;

3) ROE - return on equity, $\%$ : net profit divided by equity capital and multiplied by 100 ;

4) ROA - return on assets, \%: net profit divided by total assets and multiplied by 100 ;

5) NPV - net present value: a discounted net present value of future cash flows over the entire period, EUR; 6) IRR - internal rate of return: it is the expected compound annual rate of return that will be earned on a project or investment. Mathematically, the IRR can be found by setting the net present value (NPV) equation
(1) equal to zero (0) and solving for the rate of return (IRR) (Schmidt, 2014):

$$
0=N P V=\sum_{n=0}^{N} \frac{\mathrm{CF} \mathrm{n}}{(1+I R R)^{n}}
$$

where: $\mathrm{CF}_{\mathrm{n}}-$ cash flow $\mathrm{n}^{\text {th }}$ period; $\mathrm{N}$ - holding period;

7) gross value added of the enterprise and its associated enterprises or a group of enterprises, which is determined by the following equation (2):

$$
B P V=P V R-N n+S
$$

where PVR - value added at factor cost, EUR;

$\mathrm{Nn}$ - indirect taxes, EUR;

$\mathrm{S}$ - any subsidies, EUR;

8) value added at factor cost is computed by the following equation (3):

$$
P V R=A+K P+I c s d+K I-I p p-N c-N r
$$

where $\mathrm{A}-$ net turnover, EUR;

$\mathrm{KP}$ - capitalised output, EUR;

Icsd - income from other economic activities, EUR;

$\mathrm{KI}$ - change in stock, EUR;

Ipp - purchases of goods and services, EUR;

$\mathrm{Nc}$ - other taxes on products, which relate to turnover but are not deductible, EUR;

$\mathrm{Nr}$ - production-related duties and taxes, EUR.

\section{Results and Discussion}

Analysis of financial and investment efficiency indicators for establishing a fish processing factory.

To attract an investor being able to implement the project for the establishment of the factory using the technology developed by the EMFF project and to begin producing the products, it is important to indicatively demonstrate the investment efficiency indicators of the project. The application of financial models for investment projects is practised at the early stage, as the models serve as an instrument for making economically feasible decisions on the projects in principle and for making decisions during the design and implementation stages. Such an approach contributes to a result-focused process, in which financial and investment efficiency indicators are employed as criteria.

According to the base scenario (Table 1), investments in fixed assets are estimated at EUR $6.23 \mathrm{mln}$., among them EUR $3.32 \mathrm{mln}$. is necessary for the purchase of equipment. This scenario intends to install equipment for production of structured fish forcemeat as an intermediate product and two production lines, one for fish buns and one for fish meatball in jelly which will be the end products of the factory. The simple and discounted payback periods for the base scenario are equal to five years $(\mathrm{r}=0.05)$. The internal rate of return equals 0.35 . The direct production cost of restructured and structured fish forcemeat (which is made of sprats, a mixture of food additives, semolina and starch) is 
estimated at approximately $0.5 \mathrm{EUR} \mathrm{kg}^{-1}$. For comparison, the cost of minced white fish meat that is currently used to produce competing products is 1.3-1.6 EUR kg-1. A significant cost reduction gives an opportunity to earn a sufficient net margin to arouse interest in potential investors and implement the project. It has to be understood that the greatest risk for an investor is created by the market factor - the real success in selling the new products in the markets of the Baltic States. To achieve the sales volume planned, the new products have to gain a market share of at least $5 \%$ in the Baltic market. It is a challenge to supply high-quality innovative products, and this target could be achieved by a highly professional marketing team.

Table 1

Key financial and economic performance indicators (base scenario) for the establishment of the fishprocessing factory and the production of fish buns and fish meatballs in jelly from Baltic Sea sprats

\begin{tabular}{|c|c|c|c|}
\hline Indicator/year & 2019 & 2020 & $\begin{array}{l}2021 \text { - } \\
2028 *\end{array}$ \\
\hline Net turnover, thou. EUR & 0 & 2359 & 4717 \\
\hline EBITDA, thou. EUR & -106 & 1591 & 2906 \\
\hline EBITDA, \% & $\mathrm{x}$ & 67 & 62 \\
\hline $\begin{array}{l}\text { Net profit or loss, thou. } \\
\text { EUR }\end{array}$ & -106 & 1169 & 2061 \\
\hline Net margin, $\%$ & $\mathrm{x}$ & 50 & 44 \\
\hline ROE, \% & -4 & 16 & 14 \\
\hline ROA, $\%$ & -4 & 15 & 14 \\
\hline $\begin{array}{l}\text { Gross value added, thou. } \\
\text { EUR }\end{array}$ & -38 & 1856 & 3357 \\
\hline $\begin{array}{l}\text { Number of employees, } \\
\text { full-time equivalent }\end{array}$ & 2 & 8 & 22 \\
\hline Sprat consumption, $\mathrm{t}$ & 0 & 204 & 408 \\
\hline $\begin{array}{l}\text { Net present value, thou. } \\
\text { EUR }\end{array}$ & & 8636 & \\
\hline IRR & & 0.35 & \\
\hline $\begin{array}{l}\text { Total investment in fixed } \\
\text { assets, thou. EUR }\end{array}$ & & 6227 & \\
\hline $\begin{array}{l}\text { Investment in current } \\
\text { assets, thou. EUR }\end{array}$ & & 213 & \\
\hline
\end{tabular}

* Annual average.

Source: authors' calculations (Latvia University of ..., 2018)

To reduce the market risk, it is advised to initially implement the base scenario, considering an opportunity to expand the factory in the future and installing additional production lines at the factory for the production of other innovative products, developed by the project, from structured fish forcemeat. The most important practical result from the economic perspective is the fact that the projected investment efficiency level of the project is sufficiently high (Table 1) to arouse interest in investors and continue implementing the project, considering all the market risks. At the same time, it is important to be aware that the implementation of the project could be affected by industry-specific and general factors of the investment environment. For this reason, the implementation of resource-intensive business ideas might require more time. Nevertheless, creating a broad assortment of new, innovative products to be introduced in production that are appropriate for the fish processing subsector of Latvia is a new strength of the fisheries sector of Latvia that could contribute to tackling problems in the sector. New products being ready for introduction in production and support by competent scientists who have developed the products are available for the enterprises of the sector that can cope with challenges in the market, change and grow.

Potential economic effect from the establishment of the fish-processing factory.

Even though the positive effect of establishing the factory on the national economy of Latvia is not a significant factor from the perspective of an investor in this project, it is important from the viewpoint of the society of Latvia. If it is obvious that the factory can considerably contribute to the fisheries sector and the national economy as a whole, this project is worth supporting from the perspective of general public interests. It is advantageous for the investor to use financial assistance provided by the EMFF to establish the factory. Previously, large-scale fish processing projects in Latvia were implemented with the support of the SAPARD programme and, after joining the EU, with the support of the EU Funds. However, no such significant projects have been implemented after 2010, as the global financial crisis lowered purchasing power in significant target markets and the trade restriction imposed by the Russian Federation decreased the exports of sprat products from Latvia, thereby causing a crisis the fish-processing subsector of Latvia. That is why it is useful to project the potential economic effect of the project for the purpose of substantiating the benefit of granting financial assistance by the government.

Baltic sprats represent a strategic resource of Latvia that has to be processed in Latvia, manufacturing finished products for sale. The establishment of the factory and the new products manufactured by it could make an extra contribution to the national economy and diversify the assortment supplied by the fish-processing subsector, while at the same time causing no resource shortage threat to the other fish processors using sprats as an input. The production process at the factory is not labour intensive, as it is automated to a high extent, yet the project is expected to create 22 competitively remunerated jobs.

Table 2

Effect of the fish-processing factory establishment project on the foreign trade balance of Latvia

\begin{tabular}{lcc}
\hline \multicolumn{1}{c}{ Indicator } & $\begin{array}{c}\text { Previous } \\
\text { practice }\end{array}$ & $\begin{array}{c}\text { Base } \\
\text { scenario }\end{array}$ \\
\hline $\begin{array}{l}\text { Exports of raw sprats, t } \\
\text { Revenue from raw sprat exports, mln. }\end{array}$ & 27735 & 27327 \\
$\begin{array}{l}\text { EUR } \\
\text { Revenue from exports of structured } \\
\text { fish forcemeat products, mln. EUR* } \\
\text { Total revenue from exports, mln. }\end{array}$ & 0.55 & 5.47 \\
EUR & 5.55 & 3.15 \\
\hline
\end{tabular}

* Excluding the part of products sold in the domestic market; it was assumed the price of sprats 0.2 thou. EUR t ${ }^{-1}$ and exports remained at the 2017 level.

Source: authors' calculations (Latvia University of ..., 2018) 
The establishment of the factory will improve the foreign trade balance of Latvia, as total revenue from fish product exports are expected to rise (Table 2). Exporting unprocessed sprats and assuming that their sales price is $0.2 \mathrm{EUR} \mathrm{kg}^{-1}$, total revenue from exports would be EUR $5.5 \mathrm{mln}$. In reality, enterprises can generate higher revenue per unit of output, e.g. if freezing sprats by means of individual quick freezing equipment. Implementing the project for manufacturing structured fish forcemeat products slightly decreases revenues from raw sprat exports, whereas the revenues from processed fish products are expected to increase considerably. This economic activity will make a qualitative contribution to the assortment of processed fish products manufactured in Latvia and create new opportunities for entering western markets, mainly offsetting the loss caused by a decrease in the output of sprat products observed since 2014.

Establishing the factory for producing structured fish forcemeat products, compared with manufacturing conventional canned sprat products, will positively affect the national economy of Latvia, contributing to the GDP and foreign trade balance and, to a lesser extent, the environment. The factory establishment project has potential for further processing of sprats and generating high value-added for part of the Baltic sprats currently exported by Latvia. For this reason, other alternatives to Baltic sprat processing have to be sought, thereby taking advantage of generating higher valueadded and giving an opportunity for fishing enterprises to earn more revenue.

\section{Conclusions}

In the post-crisis period, the fish processing subsector of Latvia needs to manufacture new, innovative products from Baltic sprats that generate higher value-added than conventional canned sprat products do.

Investing EUR $6.23 \mathrm{mln}$. in establishing the fish processing factory gives an opportunity to manufacture new, innovative products from sprats caught in the Baltic Sea. In the third year of operation, the factory is expected to achieve the planned fish processing capacity $-408 \mathrm{t}$ of fish, a turnover of EUR $4.7 \mathrm{mln}$. and a net profit of EUR $2 \mathrm{mln}$. with a $44 \%$ net margin, employing 22 full-time employees.

Establishing the factory is financially beneficial not only to the investor of the project but also to the national economy, as the foreign trade balance of Latvia is expected to improve owing to an increase in total revenue from fish product exports.

Creating a broad assortment of new, innovative products to be introduced in production that are appropriate for the fish processing subsector of Latvia is a new strength of the fisheries sector of Latvia that could contribute to tackling problems in the sector. In the future, it is advised to broaden the diversity of new fish products available for introduction in production in terms of kinds of the products, taking into account the specifics of prospective markets and market segments and the aspect of investment capacity. The new products available for introduction and the growing capacity of Latvian scientists will contribute to the development of the fishprocessing subsector.

\section{Acknowledgment}

The research was promoted with the support of the European Maritime and Fisheries Fund, project No. 1600-F01101-000005 "Production of structured fish forcemeat from Baltic sea fish and its use in fish products".

\section{References}

1. Ankvica L. (2018) Marketing of fish products in Latvia in 2017 (in Latvian). In: Latvian Fisheries Yearbook 2018. Publisher: Latvian Rural Advisory and Training Centre, p. 66-75.

2. Bauman M. P. (2014) Forecasting operating profitability with DuPont analysis: Further evidence, Review of Accounting and Finance, Vol. 13 (2), pp.191-205.

3. Benga E., Hazners J. (2018) Fish production and marketing opportunities (in Latvian). In: Latvian Fisheries Yearbook 2018. Publisher: Latvian Rural Advisory and Training Centre, p. 82-86.

4. Catchpole Th. L., Ribeiro-Santos, A., Mangi, St.C., Hedley, Ch., Gray, T.S. (2017) The challenges of the landing obligation in EU fisheries. Marine Policy, Vol. 82, p. 76-86.

5. Central Statistical Bureau of Latvia (CSP) (2019) RUG020. Sale of manufactured industrial products (PRODCOM at 10-digits), (quantity, thsd euro). [accessed on 22.12.2018.]. Available at: http://data1.csb.gov.lv/pxweb/lv/rupnbuvn/rupnbuvn_ru pn_ikgad/RUG020.px/?rxid=a39c3f49-e95e-43e7-b4f0dce111b48ba1

6. Da Rocha J. M., Cervino S., Villasante S. (2012) The common fisheries policy: an enforcement problem. Marine Policy, Vol. 36(6), p.1309-1314.

7. Destura F. I., Haard N. F. (1999) Development of intermediate moisture fish patties from minced rockfish meat (Sebastes sp.). Journal of aquatic food product technology, Vol. 8(2), p. 77-94.

8. Houmes R., Jun CC., Capriotti K., Wang D. (2018) Evaluating the long-term valuation effect of efficient asset utilization and profit margin on stock returns: Additional evidence from the DuPont identity. In: Meditari Accountancy Research, Emerald Publishing Limited, Vol. 26 (1), pp.193-210.

9. Khalilian S., Froese R., Proelss A., Requate T. (2010) Designed for failure: a critique of the common fisheries policy of the European Union. Marine Policy, Vol. 34(6), p. $1178-1182$.

10. Kornilovs G., Ustups D. (2018) State of fish stocks and regulation of fishing in the Baltic Sea in 2017-2018 (in Latvian). In: Latvian Fisheries Yearbook 2018. Publisher: Latvian Rural Advisory and Training Centre, p. 43-57.

11. Laugalis A. (2009) Latvian Fisheries Policy after joining the European Union (in Latvian). Bachelor's work. University of Latvia.

12. Latvia University of Life Sciences and Technologies in cooperation with the Society for the Greatest World (2018) Final report of project No 16-00-F01101-000005 "Production of structured fish forcemeat from Baltic sea fish and its use in fish products" (in Latvian). Jelgava, May 2018, 224 p. 
13. Neiva C. R. P., Machado T. M., Tomita R. Y., Furlan É. F., Lemos Neto M. J., Bastos D. H. M. (2011) Fish crackers development from minced fish and starch: an innovative approach to a traditional product. Food Science and Technology, Vol. 31(4), p. 973-979.

14. Schmidt, R. (2014) What is IRR and How Does it Work? JUNE 9, 2014. [accessed on 2.01.2019.]. Available at: https://www.propertymetrics.com/

15. Schroeer A., Sakai C., Vulperhorst V., Białaś A. (2011) The European Union and Fishing Subsidies. September 2011, p. 16. [accessed on 3.01.2019.]. Available at: http://baltic.oceana.org/sites/baltic.oceana.org/files/EU_S ubsidies_Report_FINAL_FINAL.pdf

16. Sehgal H., Shahi M., Sehgal G. K., Thind S. S. (2008) Some quality aspects of fish patties prepared from an Indian major carp, Labeo rohita (Ham.). International journal of food sciences and nutrition, Vol. 59(3), p.192-201.

17. Sissenwine M., Symes D. (2007) Report to the general directorate for fisheries and maritime affairs of the European Commission [accessed on 01.02.2019.]. Available at: https://www.researchgate.net/publication/25 5631911_Reflections_on_the_Common_Fisheries_Policy

18. Soliman T. M. (2008) The use of DuPont analysis by market participants. The accounting Review, Vol. 83(3), p. 823-853.

19. Ministry of Agriculture (2018) Agriculture of Latvia in 2018 (in Latvian). Riga, 180 p. [accessed on 01.02.2019.]. Available https://www.zm.gov.lv/public/files/CMS_Static_ Page_Doc/00/00/01/33/19/Gadazinojums.pdf. 